\title{
ANALISIS PENGUKURAN PRODUKTIVITAS MENGGUNAKAN METODE MARVIN E. MUNDEL
}

\author{
Suparno ${ }^{1}$, Nur Hamidah ${ }^{2}$ \\ 1, 2)Program Studi Teknik Industri Universitas Qomaruddin \\ Jalan Raya No.01 Bungah Gresik \\ e-mail: suparnosttq@gmail.com
}

\begin{abstract}
Competition in many companies can be measured by the level of productivity of the company. CV. Gavra Perkasa Gresik is a manufacturing company engaged in the wood processing industry, among the products produced is turning. So far, the company has never made productivity measurements so that, if output is low, the company thinks it is not good without analyzing the causes specifically and not paying attention to the efficiency of the use of resources (inputs) that are owned. Productivity measurement to find out how the condition of the company's productivity, whether experiencing an increase or decrease, is necessary to measure productivity using the model Marvin E. Mundel. This measurement is carried out on labor input, material, energy, capital and total input. The data needed for productivity analysis is taken from 2016 as the base period and 2017 as the measurement period. The results of calculation of productivity using the mundel model not all inputs have decreased, causing the company's total productivity to be $98.18 \%$ which has a good impact on the company.
\end{abstract}

Keywords: CV. Gavra Perkas; Marvin E. Mundel; Productivity; Turning

\begin{abstract}
Abstrak
Persaingan pada banyak perusahaan dapat diukur dari tingkat produktivitas perusahaan tersebut. CV. Gavra Perkasa Gresik merupakan perusahaan manufaktur yang bergerak dalam bidang industri pengolahan kayu, diantara produk yang dihasilkan yaitu turning. Selama ini perusahaan belum pernah melakukan pengukuran produktivitas sehingga, jika output rendah maka perusahaan beranggapan tidak baik tanpa menganalisa penyebabnya secara spesisfik dan kurang memperhatikan efesiensi penggunaan sumber daya (input) yang dimiliki. Pengukuran produktivitas untuk mengetahui bagaimana kondisi produktivitas perusahaan, apakah mengalami peningkatan atau penurunan maka perlu dilakukan pengukuran produktivitas dengan menggunakan model Marvin E. Mundel. Pada pengukuran ini dilakukan pada input tenaga kerja, material, energi, modal dan input total. Data yang diperlukan untuk analisis produktivitas ini diambil dari tahun 2016 sebagai periode dasar dan tahun 2017 sebagai periode pengukuran. Hasil perhitungan produktivitas menggunakan model mundel tidak semua input mengalami penurunan, sehingga menyebabkan produktivitas total perusahaan menjadi $98,18 \%$ yang berdampak baik bagi perusahaan.
\end{abstract}

Kata kunci: CV. Gavra Perkas; Marvin E. Mundel; Produktivitas; Turning

\section{Pendahuluan}

Pada era dewasa ini persaingan dunia industri semakin ketat, sehingga perusahaan dituntut untuk terus berkembang (Singgih, 2008). Kondisi persaingan yang semakin ketat menuntut perusahaan untuk tetap bertahan dalam persaingan saat ini (Bakar et al., 2017). Perindustrian sangat erat dengan persaingan bisnis. Dalam persaingan ini perusahaan berupaya untuk tetap konsisten menghasilkan produk yang berkualitas, mengembangkan usaha dan memberikan pelayanan secara prima kepada seluruh konsumen. Dalam hal ini perusahaan dituntut untuk melakukan perbaikan - perbaikan diberbagai sektor agar dapat menghasilkan keuntungan yang dapat 
menunjang perkembangan perusahaan. Perusahaan juga perlu merencanakan dan mengembangkan strategi dalam memperbaiki kinerjanya yang lebih efektif dan efisien untuk mempertahankan eksistensinya. Persaingan pada sektor industri tidak hanya diukur dari produknya saja. akan tetapi, harus juga diukur dari tingkat produktivitanya yang tinggi. Produktivitas merupakan salah satu alternatif untuk mengevaluasi kinerja yang telah dilakukan dan merupakan salah satu cara yang sangat tepat dalam menilai efisiensi pemakaian sejumlah input dalam menghasilkan output tertentu. Produktivitas adalah perbandingan antara totalitas pengeluaran pada waktu tertentu dibagi totalitas masukan selama periode tersebut. Produktivitas juga diartikan sebagai hubungan antara hasil nyata maupun fisik (barang-barang atau jasa) dengan masuknya yang sebenarnya atau bisa diartikan suatu perbandingan antara hasil keluaran dan masuk atau output: input (Mubin \& Zainuri, 2012). Meningkatkan produktivitas suatu perusahaan juga dipengaruhi oleh factor-faktor tidak hanya untuk mendapatkan keuntungan yang tinggi, namun juga ditunjang oleh factorfaktor penting lainnya seperti sumberdaya manusia, mesin, dan proses produksinya (Kurniawan et al., 2017). Produktivitas merupakan salah satu indicator penentu bagi perusahaan untuk dapat terus membuktikan eksistensinya ditengah persaingan dengan perusahaan kompetitor (Kusumanto, 2016). Suatu perusahaan perlu mengetahui produktivitasnya agar dapat membandingkannya dengan produktivitas yang telah ditetapkan oleh manajemennya.

Hasil pengukuran dan evaluasi ini akan memberikan informasi kepada perusahaan mengenai tingkat efisiensi yang berhasil dicapai oleh perusahaan dalam melakukan aktivitasnya, hal ini menjadi penting agar perusahaan dapat meningkatkan daya saing dari produk yang dihasilkan dipasar global dengan kompetitif. Untuk itu perusahaan perlu melaksanakan pengukuran produktivitas pada tingkat perusahaan agar tingkat produksi dapat menghasilkan produk dengan kualitas yang diinginkan dengan biaya yang serendah mungkin. CV. Gavra Perkasa yang berada di daerah Panceng KM.52 A Gresik Jawa Timur merupakan perusahaan manufaktur yang bergerak dalam bidang industri pengolahan kayu, diantara produk yang dihasilkan yaitu ruji tangga (turning), handril dan sono, tetapi 122 penelitian ini difokuskan pada produk turning karena produk tersebut banyak dipesan dan diminati oleh konsumen. Gambar produk turning seperti Gambar 1 dibawah ini.

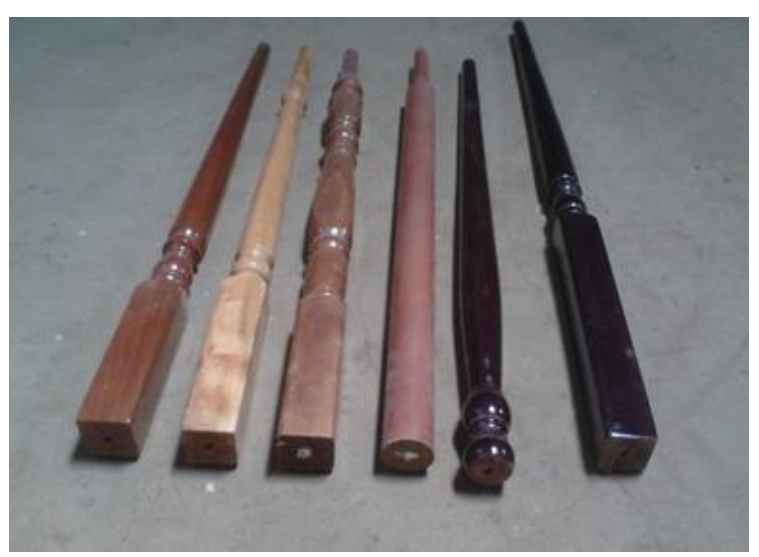

Gambar 1. Kayu Olahan Turning

Selama ini perusahaan belum pernah melakukan pengukuran produktivitas. Perusahaan hanya melihat tingkat pencapaian profit pada periode tertentu, sehingga memungkinkan perusahaan untuk mengeluarkan biaya yang besar dalam melakukan proses produksi yang berpengaruh pada penerimaan profit perusahaan. jika biaya yang dikeluarkan semakin besar maka profit yang diterima semakin kecil akibatnya perusahaan mengalami produktivitas yang cenderung tidak stabil.

Permasalahan yang ada di CV. Gavra Perkasa Gresik yaitu perusahaan hanya mengacu pada output saja sehingga jika output rendah maka perusahaan beranggapan tidak baik tanpa menganalisa penyebabnya secara spesisfik dan kurang memperhatikan efesiensi penggunaan sumber daya (input) yang dimiliki baik dari segi bahan baku, energi dan mesin yang menunjang proses produksi. Kualitas SDM yang andal adalah asset penting bagi perusahaan untuk menunjukkan kinerja perusahaan (Singgih, 2008). Dari hasil wawancara dengan Bapak Karyanto menyebutkan salah satunya pada kualitas bahan baku yang digunakan banyak kecacatan sehingga membuat kemunduran pada proses selanjutnya karena perlu pengulangan proses pada produk yang cacat dengan keterbatasan bahan baku yang disesuaikan dengan produksi yang dilakukan. Hal ini disebabkan keterlambatan dalam pemesanannya. Tabel 1 memberi gambaran mengapa meningkatkan produktivitas menjadi sangat penting.

Tabel 1. Hubungan Kualitas dan Produktivitas 


\begin{tabular}{|l|c|c|}
\hline & \multicolumn{1}{|c|}{$\begin{array}{c}\text { Sebelum } \\
\text { permintaan } \\
\text { menaikkan } \\
\text { produktivitas }\end{array}$} & $\begin{array}{c}\text { Setelah } \\
\text { permintaan } \\
\text { menaikkan } \\
\text { produktivitas } \\
\text { dengan } \\
\text { perbaikan } \\
\text { kualitas }\end{array}$ \\
\hline \multicolumn{1}{|c|}{ Bulan } & Jumlah (pcs) & Jumlah (pcs) \\
\hline Januari & 208 & 220 \\
\hline Februari & 235 & 240 \\
\hline Maret & 200 & 205 \\
\hline April & 215 & 215 \\
\hline Mei & 197 & 205 \\
\hline Juni & 206 & 210 \\
\hline Juli & 195 & 220 \\
\hline Agustus & 215 & 220 \\
\hline September & 230 & 235 \\
\hline Oktober & 200 & 210 \\
\hline Nopember & 225 & 230 \\
\hline Desember & 196 & 225 \\
\hline
\end{tabular}

Dari uraian diatas, menunjukkan bahwa pengukuran produktivitas perlu dilakukan sehingga dapat mengetahui tingkat produktivitas yang nantinya dapat dilakukan upaya peningkatan dengan cara mengetahui faktor yang mempengaruhi naik turunnya produktivitas perusahaan. Manfaat dari penelitian ini adalah untuk membantu perusahaan meningkatkan indeks produktivitas atau mempertahankan produktivitas yang ada (Mahaputra, 2018). Produktivitas ada dua yaitu produktivitas parsial dan produktivitas total (Ristanti \& Prabowo, 2018). Dalam penelitian ini pengukuran dilakukan dengan metode Marvin E. Mundel. Marvin E. Mundel mendefinisikan produktivitas sebagai rasio antara nilai barang hasil produksi dan biaya produksi yang dibandingkan dengan rasio serupa untuk periode basis (Siahaya, 2017) Marvin E. Mundel mengemukakan dua bentuk pengukuran indeks produktivitas, yaitu

$I P=\frac{A O M P / \text { Jumlah } R I M P=}{A O B P / \text { Jumlah } R I B P} \times 100$

Pers. 1

Keterangan:

$\mathrm{IP} \quad=$ Indeks Produktivitas

AOMP = Output Agregat untuk periode yang diukur

AOBP $=$ Output Agregat untuk periode dasar

RIMP = Input-input untuk periode yang diukur
RIBP = Input-input untuk periode dasar

\section{Metodologi Penelitian}

Objek penelitian adalah perusahaan yang mengolah kayu, diantara menjadi ruji tangga (turning), handril dan sono. Teknik pengumpulan data yang dilakukan penulis berupa teknik dokumentasi, teknik kepustakaan, yakni dengan membaca bukubuku dan jurnal-jurnal yang berkaitan dengan penerapan metode Marvin E Mundel. Sumber data sekunder yaitu, harga beli material, struktur produk turning, jam kerja, biaya tenaga kerja, jumlah permintaan, biaya energi, indeks harga nasional, biaya perawatan mesin dan peralatan, serta harga jual produk turning. Prosedur penelitian dilakukan dengan menentukan nilai deflator dari setiap indeks harga masukan material, indeks harga masukan depresiasi, harga konstan masukan tenaga kerja, harga konstan masukan energi, dan harga konstan masukan biaya perawatan. Menentukan harga konstan yaitu harga berlaku yang ada dikonstankan dengan nilai deflator. Untuk nilai output tidak perlu didefinisikan karena untuk mendapat nilai keluaran (output) setiap periode adalah dengan mengakibatkan jumlah hasil produksi setiap periode dengan harga jual produk yang berlakuSetelah harga konstan dari setiap input diperoleh, maka dilakukan perhitungan total input partial. Langkah berikutnya adalah menghitung produktivitas total setiap peroide pengukuran, dengan membandingkan nilai Output Partial dengan nilai Input Partial. Tahap terahir yang dilakukan adalah dengan menghitung indeks produktivitas parsial dengan membandingkan nilai indeks dari biaya material, tenaga kerja, depresiasi, energi, perawatan terhadap keluaran (output) yang dihasilkan perusahan (Rejeki et al, 2013).

\section{Hasil dan Pembahasan}

\section{Perhitungan Harga Deflator}

Deflator adalah penyeimbang atau penyesuaian harga terhadap faktor-faktor yang datang dari perusahaan. Perhitungan deflator dilakukan berdasarkan indeks harga yang diperoleh dari BPS (Badan Pusat Statistik) dengan periode pengukuran tahun 2016-2017, untuk lebih jelasnya berikut ini merupakan perhitungan yang dilakukan untuk memperoleh 
nilai konstan masukan yang dapat diperoleh dari rumus

Deflator bulan penelitian

$=\frac{\text { I.H bulan penelitian XI.H bulan dasar }}{\text { indeks harga bulan dasar }}$ Pers. 2 $=\frac{123,75 \times 123,62}{123,62}$

$=0,13$

Untuk lebih jelasnya, berikut ini hasil perhitungan deflator menurut periode pengukuran dapat dilihat pada Tabel 2 berdasarkan indeks harga yang diperoleh dari BPS (Badan Pusat Statistik) dengan periode pengukuran tahun 2016-2017.

Tabel 2. Hasil Perhitungan Deflator

\begin{tabular}{|c|c|c|c|c|c|}
\hline \multicolumn{2}{|c|}{$\begin{array}{c}\text { Periode Tahun } \\
\text { 2016 }\end{array}$} & \multicolumn{3}{c|}{$\begin{array}{c}\text { Periode Tahun } \\
\text { 2017 }\end{array}$} \\
\hline Bulan & $\begin{array}{c}\text { Indeks } \\
\text { Harga }\end{array}$ & $\begin{array}{c}\text { Defl } \\
\text { ator }\end{array}$ & Bulan & $\begin{array}{c}\text { Indeks } \\
\text { Harga }\end{array}$ & $\begin{array}{c}\text { Defl } \\
\text { ator }\end{array}$ \\
\hline Januari & 123,62 & 0,00 & Januari & 127,94 & 4,32 \\
\hline Februari & 123,51 & $-0,11$ & Februari & 128,24 & 4,62 \\
\hline Maret & 123,75 & 0,13 & Maret & 128,22 & 4,60 \\
\hline April & 123,19 & $-0,43$ & April & 128,33 & 4,71 \\
\hline Mei & 123,48 & $-0,14$ & Mei & 123,48 & NA \\
\hline Juni & 124,29 & 0,67 & Juni & 124,29 & NA \\
\hline Juli & 125,15 & 1,53 & Juli & 125,15 & NA \\
\hline Agustus & 125,13 & 1,51 & Agustus & 125,13 & NA \\
\hline $\begin{array}{c}\text { Septem } \\
\text { ber }\end{array}$ & 125,41 & 1,79 & $\begin{array}{c}\text { Septemb } \\
\text { er }\end{array}$ & 125,41 & NA \\
\hline Oktober & 125,59 & 1,97 & Oktober & 125,59 & NA \\
\hline $\begin{array}{c}\text { Novemb } \\
\text { er }\end{array}$ & 126,18 & 2,56 & $\begin{array}{c}\text { Novemb } \\
\text { er }\end{array}$ & 126,18 & NA \\
\hline $\begin{array}{c}\text { Desemb } \\
\text { er }\end{array}$ & 126,71 & 3,09 & $\begin{array}{c}\text { Desemb } \\
\text { er }\end{array}$ & 126,71 & NA \\
\hline
\end{tabular}

\section{Perhitungan Harga Konstan}

Harga konstan perlu ditentukan bila di-la-kukan pengukuran produktivitas berdasarkan harga (Purwanti et al., 2013). Hal ini bertujuan untuk penyeimbang berbagai kondisi perekonomian yang dapat mempengaruhi harga-harga yang berlaku. Untuk lebih jelasnya, berikut ini merupakan perhitungan harga konstan yang dapat dilakukan dengan rumus dibawah ini.

Harga Konstan =

Nilai periode yang bersangkutan X 100 $100+$ Deflator

Pers. 3
Harga Konstan Material dilakukan dari data biaya material kemudian harga berlaku yang ada dikonstankan dengan nilai deflator. Perhitungan harga konstan material dilakukan menurut periode dasar yaitu bulan Januari untuk mengetahui harga konstan di bulan Februari. Tabel 3 menunjukan harga konstan.

Tabel 3. Harga Konstan Material

\begin{tabular}{|c|c|c|c|c|c|}
\hline $\begin{array}{c}\text { Tah } \\
\text { un }\end{array}$ & Bulan & $\begin{array}{c}\text { Biaya } \\
\text { (Rp) }\end{array}$ & $\begin{array}{c}\text { Tah } \\
\text { un }\end{array}$ & Bulan & $\begin{array}{c}\text { Biaya } \\
(\mathrm{Rp})\end{array}$ \\
\hline \multirow{12}{*}{$\begin{array}{l}20 \\
16\end{array}$} & Januari & $\begin{array}{c}73788 \\
0000\end{array}$ & \multirow{12}{*}{$\begin{array}{l}20 \\
17\end{array}$} & Januari & $\begin{array}{c}74497 \\
5004\end{array}$ \\
\hline & $\begin{array}{c}\text { Februa } \\
\text { ri }\end{array}$ & $\begin{array}{c}85206 \\
9999\end{array}$ & & $\begin{array}{c}\text { Februa } \\
\text { ri }\end{array}$ & $\begin{array}{c}79818 \\
7504\end{array}$ \\
\hline & Maret & $\begin{array}{c}82302 \\
0000\end{array}$ & & Maret & $\begin{array}{c}81592 \\
5004\end{array}$ \\
\hline & April & $\begin{array}{c}76271 \\
2499\end{array}$ & & April & $\begin{array}{c}84075 \\
7504\end{array}$ \\
\hline & Mei & $\begin{array}{c}69885 \\
7499\end{array}$ & & Mei & \\
\hline & Juni & $\begin{array}{c}73078 \\
5000\end{array}$ & & Juni & \\
\hline & Juli & $\begin{array}{c}69176 \\
2501\end{array}$ & & Juli & \\
\hline & $\begin{array}{l}\text { Agus } \\
\text { tus }\end{array}$ & $\begin{array}{c}77335 \\
5001\end{array}$ & & $\begin{array}{c}\text { Agus } \\
\text { tus }\end{array}$ & \\
\hline & $\begin{array}{c}\text { Septem } \\
\text { ber }\end{array}$ & $\begin{array}{c}81592 \\
5001\end{array}$ & & $\begin{array}{c}\text { Septem } \\
\text { ber }\end{array}$ & \\
\hline & $\begin{array}{l}\text { Okto } \\
\text { ber }\end{array}$ & $\begin{array}{c}70950 \\
0001\end{array}$ & & $\begin{array}{l}\text { Okto } \\
\text { ber }\end{array}$ & \\
\hline & $\begin{array}{c}\text { Novem } \\
\text { ber }\end{array}$ & $\begin{array}{c}84075 \\
7502\end{array}$ & & $\begin{array}{c}\text { Novem } \\
\text { ber }\end{array}$ & \\
\hline & $\begin{array}{c}\text { Desem } \\
\text { ber }\end{array}$ & $\begin{array}{c}69531 \\
0003\end{array}$ & & $\begin{array}{c}\text { Desem } \\
\text { ber }\end{array}$ & \\
\hline
\end{tabular}

\section{Harga Konstan Masukan Depresiasi (RIP 2)}

Harga konstan masukan depresiasi pada Tabel 4 diambil dari data biaya depresiasi yang kemudian dikonstankan dengan nilai deflator berdasarkan periode dasar yaitu bulan Januari untuk mencari harga konstan dibulan Februari.

Tabel 4. Harga Konstan Masukan Depresiasi

\begin{tabular}{|c|c|c|c|}
\hline $\begin{array}{c}\text { Peride } \\
\text { tahun 2016 }\end{array}$ & $\begin{array}{c}\text { Biaya } \\
\text { (Rp) }\end{array}$ & $\begin{array}{c}\text { Periode } \\
\text { tahun 2017 }\end{array}$ & $\begin{array}{c}\text { Biaya } \\
\text { (Rp) }\end{array}$ \\
\hline Januari & 8592500 & Januari & 8936204 \\
\hline Februari & 8248799 & Februari & 8248804 \\
\hline \multicolumn{4}{|c}{} \\
\hline
\end{tabular}

\section{Harga Konstan Masukan Material (RIP 1)}


Tabel 4. Harga Konstan Masukan Depresiasi (lanjutan)

\begin{tabular}{|c|c|c|c|}
\hline $\begin{array}{c}\text { Peride } \\
\text { tahun 2016 }\end{array}$ & $\begin{array}{c}\text { Biaya } \\
(\mathbf{R p})\end{array}$ & $\begin{array}{c}\text { Periode } \\
\text { tahun 2017 }\end{array}$ & $\begin{array}{c}\text { Biaya } \\
(\mathbf{R p})\end{array}$ \\
\hline Maret & 8936200 & Maret & 8592504 \\
\hline April & 8936199 & April & 8936204 \\
\hline Mei & 8592499 & Mei & \\
\hline Juni & 8592500 & Juni & \\
\hline Juli & 8936201 & Juli & \\
\hline Agustus & 8592501 & Agustus & \\
\hline September & 8936201 & September & \\
\hline Oktober & 8592501 & Oktober & \\
\hline November & 8936202 & November & \\
\hline Desember & 8592503 & Desember & \multicolumn{1}{|l}{} \\
\hline
\end{tabular}

\section{Harga Konstan Masukan Tenaga Kerja (RIP 3)}

Harga konstan masukan tenaga kerja dapat diperoleh dari masukan biaya tenaga kerja yang pengukurannya dilakukan untuk tiap bulannya. Dari biaya tenaga kerja tersebut kemudian dikonstankan dengan nilai deflator. Rumus yang digunakan sama dengan yang sudah dicontohkan seperti diatas. Untuk lebih jelasnya, berikut ini merupakan data hasil perhitungan harga konstan masukan depresiasi menurut periode pengukurannya yaitu ditahun 2016 dan 2017 yang dapat dilihat pada Tabel 5.

Tabel 5. Harga Konstan Masukan Tenaga Kerja

\begin{tabular}{|c|c|c|c|c|c|}
\hline $\begin{array}{c}\text { Tah } \\
\text { un }\end{array}$ & Bulan & $\begin{array}{c}\text { Biaya } \\
\text { (Rp) }\end{array}$ & $\begin{array}{c}\text { Tah } \\
\text { un }\end{array}$ & Bulan & $\begin{array}{c}\text { Biaya } \\
\text { (Rp) }\end{array}$ \\
\hline \multirow{8}{*}{$\begin{array}{l}20 \\
16\end{array}$} & Januari & $\begin{array}{c}15591 \\
0000\end{array}$ & \multirow{8}{*}{$\begin{array}{l}20 \\
17\end{array}$} & Januari & $\begin{array}{c}14685 \\
8004\end{array}$ \\
\hline & Februari & $\begin{array}{c}15590 \\
9999\end{array}$ & & $\underset{\mathrm{ri}}{\text { Februa }}$ & $\begin{array}{c}14685 \\
8004\end{array}$ \\
\hline & Maret & $\begin{array}{c}15591 \\
0000\end{array}$ & & Maret & $\begin{array}{c}14685 \\
8004\end{array}$ \\
\hline & April & $\begin{array}{c}15590 \\
9999\end{array}$ & & April & $\begin{array}{c}14685 \\
8004\end{array}$ \\
\hline & Mei & $\begin{array}{c}15590 \\
9999\end{array}$ & & Mei & \\
\hline & Juni & $\begin{array}{c}15591 \\
0000\end{array}$ & & Juni & \\
\hline & Juli & $\begin{array}{c}15591 \\
0001\end{array}$ & & Juli & \\
\hline & Agustus & $\begin{array}{c}15591 \\
0001\end{array}$ & & $\begin{array}{c}\text { Agustu } \\
\mathrm{s}\end{array}$ & \\
\hline
\end{tabular}

(lanjut)
Tabel 5. Harga Konstan Masukan Tenaga Kerja (lanjutan)

\begin{tabular}{|c|c|c|c|c|c|}
\hline $\begin{array}{c}\text { Tah } \\
\text { un }\end{array}$ & Bulan & $\begin{array}{l}\text { Biaya } \\
\text { (Rp) }\end{array}$ & $\begin{array}{l}\text { Tah } \\
\text { un }\end{array}$ & Bulan & $\begin{array}{c}\text { Biaya } \\
\text { (Rp) }\end{array}$ \\
\hline & $\begin{array}{c}\text { Septemb } \\
\text { er }\end{array}$ & $\begin{array}{c}15591 \\
0001\end{array}$ & & $\begin{array}{l}\text { Septem } \\
\text { ber }\end{array}$ & \\
\hline & Oktober & $\begin{array}{l}15591 \\
0001\end{array}$ & & $\begin{array}{c}\text { Oktobe } \\
r\end{array}$ & \\
\hline & $\begin{array}{c}\text { Novemb } \\
\text { er }\end{array}$ & $\begin{array}{c}15591 \\
0002\end{array}$ & & $\begin{array}{c}\text { Novem } \\
\text { ber }\end{array}$ & \\
\hline & $\begin{array}{c}\text { Desemb } \\
\text { er }\end{array}$ & $\begin{array}{c}15591 \\
0003\end{array}$ & & $\begin{array}{c}\text { Desem } \\
\text { ber }\end{array}$ & \\
\hline
\end{tabular}

\section{Harga Konstan Masukan Energi (RIP 4)}

Harga konstan masukan energi diambil dari data biaya energi kemudian dihitung dengan mengonstankan biaya energi tersebut dengan nilai deflator. Untuk lebih jelasnya, berikut ini merupakan harga konstan energi untu setiap periode pengukurannya, untuk lebih jelanya dapat dilihat pada Tabel 6 .

Tabel 6. Harga Konstan Masukan Energi

\begin{tabular}{|c|c|c|c|c|c|}
\hline $\begin{array}{l}\text { Tah } \\
\text { un }\end{array}$ & Bulan & $\begin{array}{c}\text { Biaya } \\
\text { (Rp) }\end{array}$ & $\begin{array}{c}\text { Tah } \\
\text { un }\end{array}$ & Bulan & $\begin{array}{c}\text { Biaya } \\
\text { (Rp) }\end{array}$ \\
\hline \multirow{12}{*}{2016} & $\begin{array}{c}\text { Janua } \\
\text { ri }\end{array}$ & $\begin{array}{c}6.100 .8 \\
00\end{array}$ & \multirow{12}{*}{2017} & $\begin{array}{c}\text { Janua } \\
\text { ri }\end{array}$ & $\begin{array}{c}7.300 .8 \\
04\end{array}$ \\
\hline & $\begin{array}{c}\text { Febru } \\
\text { ari }\end{array}$ & $\begin{array}{c}9.177 .9 \\
99\end{array}$ & & $\begin{array}{c}\text { Febru } \\
\text { ari }\end{array}$ & $\begin{array}{c}8.023 .4 \\
04\end{array}$ \\
\hline & Maret & $\begin{array}{c}7.600 .0 \\
00\end{array}$ & & Maret & $\begin{array}{c}8.500 .0 \\
04\end{array}$ \\
\hline & April & $\begin{array}{c}7.199 .9 \\
99\end{array}$ & & April & $\begin{array}{c}9.700 .3 \\
04\end{array}$ \\
\hline & Mei & $\begin{array}{c}9.699 .9 \\
99\end{array}$ & & Mei & \\
\hline & Juni & $\begin{array}{c}7.200 .8 \\
00\end{array}$ & & Juni & \\
\hline & Juli & $\begin{array}{c}5.250 .9 \\
01\end{array}$ & & Juli & \\
\hline & $\begin{array}{c}\text { Agust } \\
\text { us }\end{array}$ & $\begin{array}{c}8.000 .0 \\
01\end{array}$ & & $\begin{array}{c}\text { Agust } \\
\text { us }\end{array}$ & \\
\hline & $\begin{array}{l}\text { Septe } \\
\text { mber }\end{array}$ & $\begin{array}{c}6.000 .0 \\
01\end{array}$ & & $\begin{array}{l}\text { Septe } \\
\text { mber }\end{array}$ & \\
\hline & $\begin{array}{c}\text { Oktob } \\
\text { er }\end{array}$ & $\begin{array}{c}7.624 .3 \\
01\end{array}$ & & $\begin{array}{c}\text { Oktob } \\
\text { er }\end{array}$ & \\
\hline & $\begin{array}{l}\text { Nove } \\
\text { mber }\end{array}$ & $\begin{array}{c}5.800 .0 \\
02\end{array}$ & & $\begin{array}{l}\text { Nove } \\
\text { mber }\end{array}$ & \\
\hline & $\begin{array}{l}\text { Dese } \\
\text { mber }\end{array}$ & $\begin{array}{c}7.400 .8 \\
93\end{array}$ & & $\begin{array}{l}\text { Dese } \\
\text { mber }\end{array}$ & \\
\hline
\end{tabular}

\section{Harga Konstan Masukan Maintenance (RIP 5)}

Harga konstan untuk masukan maintenance diperoleh dari data biaya maintenace yang kemudian dikonstankan dengan nilai deflator dengan periode pengukuran menurut periode dasarnya yaitu dibulan januari. Untuk perhitungan dibulan februari sama dengan 
rumus yang digunakan diatas. Untuk lebih jelasnya, Berikut ini merupakan data harga konstan masukan maintenance untuk setiap periode pengukurannya yang dapat dilihat pada Tabel 7.

Tabel 7. Harga Konstan Masukan Maintenance

\begin{tabular}{|c|c|c|c|c|c|}
\hline $\begin{array}{l}\text { Tah } \\
\text { un }\end{array}$ & Bulan & $\begin{array}{c}\text { Biaya } \\
\text { (Rp) }\end{array}$ & $\begin{array}{l}\text { Tah } \\
\text { un }\end{array}$ & Bulan & $\begin{array}{c}\text { Biaya } \\
\text { (Rp) }\end{array}$ \\
\hline \multirow{12}{*}{2016} & Januari & $\begin{array}{c}74430 \\
00\end{array}$ & \multirow{12}{*}{2017} & Januari & $\begin{array}{c}62500 \\
04\end{array}$ \\
\hline & $\underset{\mathrm{ri}}{\text { Februa }}$ & $\begin{array}{c}71249 \\
99\end{array}$ & & $\underset{\mathrm{ri}}{\text { Februa }}$ & $\begin{array}{c}75000 \\
04\end{array}$ \\
\hline & Maret & $\begin{array}{c}88480 \\
00\end{array}$ & & Maret & $\begin{array}{c}68000 \\
04\end{array}$ \\
\hline & April & $\begin{array}{c}77679 \\
99\end{array}$ & & April & $\begin{array}{c}80000 \\
04\end{array}$ \\
\hline & Mei & $\begin{array}{c}96979 \\
99\end{array}$ & & Mei & \\
\hline & Juni & $\begin{array}{c}42680 \\
00\end{array}$ & & Juni & \\
\hline & Juli & $\begin{array}{c}96600 \\
01\end{array}$ & & Juli & \\
\hline & $\begin{array}{c}\text { Agustu } \\
\mathrm{s}\end{array}$ & $\begin{array}{c}44500 \\
01\end{array}$ & & $\begin{array}{c}\text { Agustu } \\
\mathrm{s}\end{array}$ & \\
\hline & $\begin{array}{c}\text { Septem } \\
\text { ber }\end{array}$ & $\begin{array}{c}63500 \\
01\end{array}$ & & $\begin{array}{c}\text { Septem } \\
\text { ber }\end{array}$ & \\
\hline & $\begin{array}{c}\text { Oktobe } \\
r\end{array}$ & $\begin{array}{c}78500 \\
01\end{array}$ & & $\begin{array}{c}\text { Oktobe } \\
r\end{array}$ & \\
\hline & $\begin{array}{c}\text { Novem } \\
\text { ber }\end{array}$ & $\begin{array}{c}54800 \\
02\end{array}$ & & $\begin{array}{c}\text { Novem } \\
\text { ber }\end{array}$ & \\
\hline & $\begin{array}{c}\text { Desem } \\
\text { ber }\end{array}$ & $\begin{array}{c}85000 \\
03\end{array}$ & & $\begin{array}{c}\text { Desem } \\
\text { ber }\end{array}$ & \\
\hline
\end{tabular}

\section{Perhitungan Total Resources Input Partial} (RIP)

Setelah harga konstan untuk tiap masukan didapatkan maka kemudian dilakukan perhitungan total resources input partial (RIP) yang merupakan penjumlahan dari seluruh input dengan harga konstan. Untuk lebih jelasnya, berikut ini merupakan contoh perhitungan dari total RIP pada periode pengukuran bulan Januari 2016 yang dapat dilihat dibawah ini:

RIP Total $=$

$=$ RIP 1 bulan januari + RIP 2 bulan januari +

RIP 3 bulan januari + RIP 4 bulan januari +

RIP 5 bulan januari

$=7378800000+8592500+155910000+$

$7443000+6800100$

$=915926300$

Dari contoh perhitungan RIP (resources input partial) diatas, Sudah diketahui hasil dari total RIP dibulan januari, untuk perhitungan RIP selanjutnya dapat dilakukan sesuai rumus yang sudah ada. Untuk lebih jelasnya, berikut ini merupakan tabel dari total RIP (resources input partial) menurut periode pengukuran yang dimulai dari periode dasar yaitu bulan januari 2016. Hasil perhitungan dapat dilihat pada Tabel 8.

Tabel 8. Perhitungan resources input partial

\begin{tabular}{|c|c|c|c|c|c|}
\hline $\begin{array}{l}\text { Tah } \\
\text { un }\end{array}$ & Bulan & $\begin{array}{l}\text { RIP } \\
\text { Total }\end{array}$ & $\begin{array}{c}\text { Tah } \\
\text { un }\end{array}$ & Bulan & $\begin{array}{c}\text { RIP } \\
\text { Total }\end{array}$ \\
\hline \multirow{12}{*}{$\begin{array}{l}20 \\
16\end{array}$} & $\underset{i}{\text { Januar }}$ & $\begin{array}{c}915.926 \\
.300\end{array}$ & \multirow{12}{*}{$\begin{array}{l}20 \\
17\end{array}$} & $\underset{\mathrm{i}}{\text { Januar }}$ & $\begin{array}{c}914.320 . \\
020\end{array}$ \\
\hline & $\begin{array}{c}\text { Febru } \\
\text { ari }\end{array}$ & $\begin{array}{c}932.531 \\
.795\end{array}$ & & $\underset{\mathrm{ri}}{\text { Februa }}$ & $\begin{array}{c}968.817 . \\
720\end{array}$ \\
\hline & Maret & $\begin{array}{l}1.004 .3 \\
14.200\end{array}$ & & Maret & $\begin{array}{c}985.675 . \\
520\end{array}$ \\
\hline & April & $\begin{array}{c}942.526 \\
.695\end{array}$ & & April & $\begin{array}{c}1.014 .25 \\
2.170\end{array}$ \\
\hline & Mei & $\begin{array}{c}882.757 \\
.995\end{array}$ & & Mei & \\
\hline & Juni & $\begin{array}{c}905.756 \\
.300\end{array}$ & & Juni & \\
\hline & Juli & $\begin{array}{c}771.519 \\
.605 \\
\end{array}$ & & Juli & \\
\hline & $\begin{array}{l}\text { Agust } \\
\text { us }\end{array}$ & $\begin{array}{c}950.307 \\
.505\end{array}$ & & $\begin{array}{c}\text { Agustu } \\
\mathrm{s}\end{array}$ & \\
\hline & $\begin{array}{l}\text { Septe } \\
\text { mber }\end{array}$ & $\begin{array}{c}992.121 \\
.205\end{array}$ & & $\begin{array}{l}\text { Septe } \\
\text { mber }\end{array}$ & \\
\hline & $\begin{array}{c}\text { Oktob } \\
\text { er }\end{array}$ & $\begin{array}{c}789.476 \\
.805\end{array}$ & & $\begin{array}{c}\text { Oktobe } \\
r\end{array}$ & \\
\hline & $\begin{array}{l}\text { Nope } \\
\text { mber }\end{array}$ & $\begin{array}{c}916.883 \\
.710\end{array}$ & & $\begin{array}{c}\text { Nopem } \\
\text { ber }\end{array}$ & \\
\hline & $\begin{array}{l}\text { Dese } \\
\text { mber }\end{array}$ & $\begin{array}{c}874.613 \\
.405\end{array}$ & & $\begin{array}{c}\text { Desem } \\
\text { ber }\end{array}$ & \\
\hline
\end{tabular}

\section{Perhitungan Agregat Output}

Perhitungan agregat output dilakukan selama periode pengukuran 2016-2017, dapat diperoleh dengan mengkalikan jumlah output (turning) dengan harga per kubik. Untuk lebih jelasnya dapat menggunakan rumus dibawah ini:

Agregat output $=$ jumlah produksi turning $\mathrm{x}$ harga jual per kubik turning

Pers. 4

$$
\begin{aligned}
& =208 \times 4800000 \\
& =998400000
\end{aligned}
$$

Dari rumus diatas dapat diperoleh perencanaan produk yang dihasilkan oleh perusahaan untuk tiap bulannya. Perusahaan melakukan perencanaan untuk memperoleh suatu pemecahan yang optimal dalam memperoleh keuntungan pada periode yang direncanakan. Dengan cara yang sama dilakukan perhitungan sesuai dengan periode pengukuran untuk tiap bulannya. Untuk lebih jelasnya, berikut ini merupakan hasil dari nilai agregat output untuk bulan selanjutnya yang dapat dilihat pada Tabel 9. 
Tabel 9. Hasil Agregat Output Untuk Periode Pengukuran

\begin{tabular}{|c|c|c|c|c|c|}
\hline $\begin{array}{l}\text { Tah } \\
\text { un }\end{array}$ & Bulan & $\begin{array}{c}\text { Agregat } \\
\text { Output }\end{array}$ & $\begin{array}{l}\text { Tah } \\
\text { un }\end{array}$ & Bulan & $\begin{array}{c}\text { RIP } \\
\text { Total }\end{array}$ \\
\hline \multirow{12}{*}{$\begin{array}{l}20 \\
16\end{array}$} & $\underset{i}{\text { Januar }}$ & $\begin{array}{c}9984000 \\
00\end{array}$ & \multirow{12}{*}{$\begin{array}{l}20 \\
17\end{array}$} & $\underset{i}{\text { Januar }}$ & $\begin{array}{c}100800 \\
0000\end{array}$ \\
\hline & $\underset{\mathrm{ri}}{\text { Februa }}$ & $\begin{array}{c}1017600 \\
000\end{array}$ & & $\begin{array}{c}\text { Febru } \\
\text { ari }\end{array}$ & $\begin{array}{c}108000 \\
0000\end{array}$ \\
\hline & Maret & $\begin{array}{c}1113600 \\
000\end{array}$ & & Maret & $\begin{array}{c}110400 \\
0000\end{array}$ \\
\hline & April & $\begin{array}{c}1032000 \\
000\end{array}$ & & April & $\begin{array}{c}113760 \\
0000\end{array}$ \\
\hline & Mei & $\begin{array}{c}9456000 \\
00\end{array}$ & & Mei & \\
\hline & Juni & $\begin{array}{c}9888000 \\
00\end{array}$ & & Juni & \\
\hline & Juli & $\begin{array}{c}9360000 \\
00\end{array}$ & & Juli & \\
\hline & $\begin{array}{c}\text { Agustu } \\
\mathrm{s}\end{array}$ & $\begin{array}{c}1046400 \\
000\end{array}$ & & $\begin{array}{c}\text { Agustu } \\
\mathrm{s}\end{array}$ & \\
\hline & $\begin{array}{l}\text { Septe } \\
\text { mber }\end{array}$ & $\begin{array}{c}1104000 \\
000\end{array}$ & & $\begin{array}{l}\text { Septe } \\
\text { mber }\end{array}$ & \\
\hline & $\begin{array}{c}\text { Oktobe } \\
r\end{array}$ & $\begin{array}{c}9600000 \\
00\end{array}$ & & $\begin{array}{c}\text { Oktob } \\
\text { er }\end{array}$ & \\
\hline & $\begin{array}{c}\text { Nopem } \\
\text { ber }\end{array}$ & $\begin{array}{c}1137600 \\
000\end{array}$ & & $\begin{array}{l}\text { Nope } \\
\text { mber }\end{array}$ & \\
\hline & $\begin{array}{c}\text { Desem } \\
\text { ber }\end{array}$ & $\begin{array}{c}9408000 \\
00\end{array}$ & & $\begin{array}{l}\text { Dese } \\
\text { mber }\end{array}$ & \\
\hline
\end{tabular}

\section{Produktivitas Depresiasi}

Produktivitas depresiasi adalah perbandingan antara indeks keluaran dengan indeks depresiasi. Berikut ini rumus indeks produktivitas yang dapat dilihat dibawah ini serta hasil perhitungan di Tabel 10.

IP Parsial $=($ AOMP $/$ AOBP $) /($ RIMP $/$ RIBP $) \times 100$

Pers. 5

Dengan rumus indeks produktivitas di atas, berikut ini contoh perhitungan indeks produktivitas depresiasi untuk bulan februari tahun 2016:

$$
\begin{aligned}
\text { IP Parsial }= & (1017600000 / 998400000) / \\
& (8248799 / 8592500) \times 100 \\
= & 1.019 / 0.959 \times 100 \\
= & 106.25
\end{aligned}
$$

Tabel 10. Indeks Produktivitas Penggunaan Depresiasi

\begin{tabular}{|c|c|c|c|c|c|}
\hline \multicolumn{6}{|c|}{ Periode 2016-2017 } \\
\hline $\begin{array}{l}\text { Bul } \\
\text { an }\end{array}$ & $\begin{array}{c}\text { Keluar } \\
\text { an } \\
\text { Depre } \\
\text { siasi } \\
\text { (Rp) }\end{array}$ & $\begin{array}{l}\text { Indek } \\
\text { s } \\
\text { Keluar } \\
\text { an }\end{array}$ & $\begin{array}{c}\text { Masuk } \\
\text { an } \\
\text { Depre } \\
\text { siasi } \\
(\mathrm{Rp})\end{array}$ & $\begin{array}{c}\text { Indek } \\
\text { s } \\
\text { Masuk } \\
\text { an }\end{array}$ & $\begin{array}{c}\text { Indeks } \\
\text { Produk } \\
\text { tivitas } \\
(\%)\end{array}$ \\
\hline Mei & $\begin{array}{c}94560 \\
0000\end{array}$ & 0.947 & $\begin{array}{c}85924 \\
99\end{array}$ & 0.999 & 94,79 \\
\hline Juni & $\begin{array}{c}88880 \\
0000\end{array}$ & 0.790 & $\begin{array}{c}82925 \\
00\end{array}$ & 1.005 & 79 \\
\hline Juli & $\begin{array}{c}93600 \\
0000 \\
\end{array}$ & 0.937 & $\begin{array}{c}89362 \\
01 \\
\end{array}$ & 1.040 & 90,14 \\
\hline $\begin{array}{l}\text { Agu } \\
\text { stus }\end{array}$ & $\begin{array}{l}10464 \\
00000\end{array}$ & 1.048 & $\begin{array}{c}85925 \\
01\end{array}$ & 1.000 & 104,8 \\
\hline $\begin{array}{l}\text { Sep } \\
\text { tem } \\
\text { ber }\end{array}$ & $\begin{array}{l}11040 \\
00000\end{array}$ & 1.105 & $\begin{array}{c}89362 \\
01\end{array}$ & 1.040 & 106,25 \\
\hline $\begin{array}{c}\text { Okt } \\
\text { ober }\end{array}$ & $\begin{array}{c}96000 \\
0000 \\
\end{array}$ & 0.961 & $\begin{array}{c}85925 \\
01\end{array}$ & 1.000 & 96,15 \\
\hline $\begin{array}{c}\text { Nov } \\
\text { emb } \\
\text { er }\end{array}$ & $\begin{array}{l}11376 \\
00000\end{array}$ & 1.139 & $\begin{array}{c}89262 \\
02\end{array}$ & 1.037 & 106,5 \\
\hline $\begin{array}{c}\text { Des } \\
\text { emb } \\
\text { er }\end{array}$ & $\begin{array}{c}94080 \\
0000\end{array}$ & 0.890 & $\begin{array}{c}85925 \\
03\end{array}$ & 1.000 & 89 \\
\hline $\begin{array}{l}\text { Jan } \\
\text { uari }\end{array}$ & $\begin{array}{l}10080 \\
00000\end{array}$ & 0.961 & $\begin{array}{c}89362 \\
04\end{array}$ & 1.040 & 92,04 \\
\hline $\begin{array}{l}\text { Feb } \\
\text { ruari }\end{array}$ & $\begin{array}{l}10800 \\
00000 \\
\end{array}$ & 0.941 & $\begin{array}{c}82488 \\
04 \\
\end{array}$ & 0.960 & 98,02 \\
\hline $\begin{array}{c}\text { Mar } \\
\text { et }\end{array}$ & $\begin{array}{l}11040 \\
00000 \\
\end{array}$ & 1.009 & $\begin{array}{c}85925 \\
04\end{array}$ & 1.000 & 100,9 \\
\hline April & $\begin{array}{l}11376 \\
00000\end{array}$ & 0.995 & $\begin{array}{c}89362 \\
04\end{array}$ & 1.040 & 95,67 \\
\hline
\end{tabular}

\begin{tabular}{|c|c|c|c|c|c|}
\hline \multicolumn{7}{|c|}{ Periode 2016-2017 } \\
\hline $\begin{array}{c}\text { Bul } \\
\text { an }\end{array}$ & $\begin{array}{c}\text { Keluar } \\
\text { an } \\
\text { Depre } \\
\text { siasi } \\
\text { (Rp) }\end{array}$ & $\begin{array}{c}\text { Indek } \\
\text { s } \\
\text { Keluar } \\
\text { an }\end{array}$ & $\begin{array}{c}\text { Masuk } \\
\text { an } \\
\text { Depre } \\
\text { siasi } \\
\text { (Rp) }\end{array}$ & $\begin{array}{c}\text { Indek } \\
\text { s } \\
\text { Masuk } \\
\text { an }\end{array}$ & $\begin{array}{c}\text { Indeks } \\
\text { Produk } \\
\text { tivitas } \\
\text { (\%) }\end{array}$ \\
\hline $\begin{array}{c}\text { Jan } \\
\text { uari }\end{array}$ & $\begin{array}{c}99840 \\
0000\end{array}$ & 1.000 & $\begin{array}{c}85925 \\
00\end{array}$ & 1.000 & 100 \\
\hline $\begin{array}{c}\text { Feb } \\
\text { ruari }\end{array}$ & $\begin{array}{c}10176 \\
00000\end{array}$ & 1.019 & $\begin{array}{c}82487 \\
99\end{array}$ & 0.959 & 106,25 \\
\hline $\begin{array}{c}\text { Mar } \\
\text { et }\end{array}$ & $\begin{array}{c}11136 \\
00000\end{array}$ & 1.117 & $\begin{array}{c}89362 \\
00\end{array}$ & 1.04 & 107,4 \\
\hline April & 10320 & 1.033 & 89361 & 1.040 & 99,32 \\
\hline \multicolumn{7}{|c|}{} \\
\hline
\end{tabular}

Tabel 10. Indeks Produktivitas Penggunaan Depresiasi (lanjutan)

Produktivitas Material (Sarjono, 2001) :

IP Parsial $=($ AOMP $/$ AOBP $) /($ RIMP $/$ RIBP $) \times 100 \quad$ Pers. 6 $=(1017600000 / 998400000) /(852069999 /$ $737880000) \times 100$

$=1.019 / 1.154 \times 100=88,30$

Tabel 11 menunjukkan hasil perhitungan produktivitas material.

Tabel 11. Indeks Produktivitas Penggunaan Material

\begin{tabular}{|c|c|c|c|c|c|}
\hline \multicolumn{7}{|c|}{ Bulan } & $\begin{array}{c}\text { Kelu } \\
\text { aran } \\
\text { Materia } \\
\text { I (Rp) }\end{array}$ & $\begin{array}{c}\text { Ind } \\
\text { eks } \\
\text { Kelu } \\
\text { aran }\end{array}$ & $\begin{array}{c}\text { Masuk } \\
\text { an } \\
\text { Materi } \\
\text { al (Rp) }\end{array}$ & $\begin{array}{c}\text { Ind } \\
\text { eks } \\
\text { Masu } \\
\text { kan }\end{array}$ & $\begin{array}{c}\text { Ind } \\
\text { eks } \\
\text { Prod } \\
\text { uktivi } \\
\text { tas } \\
(\%)\end{array}$ \\
\hline $\begin{array}{c}\text { Januar } \\
\text { i }\end{array}$ & $\begin{array}{c}998400 \\
000\end{array}$ & 1.000 & $\begin{array}{c}73788 \\
0000\end{array}$ & 1.000 & 100 \\
\hline $\begin{array}{c}\text { Februa } \\
\text { ri }\end{array}$ & $\begin{array}{c}101760 \\
0000\end{array}$ & 1.019 & $\begin{array}{c}85206 \\
9999\end{array}$ & 1.154 & 88,30 \\
\hline Maret & $\begin{array}{c}111360 \\
0000\end{array}$ & 1.117 & $\begin{array}{c}82302 \\
0000\end{array}$ & 1.115 & 99,85 \\
\hline April & $\begin{array}{c}103200 \\
0000\end{array}$ & 1.033 & $\begin{array}{c}76271 \\
2499\end{array}$ & 1.033 & $\begin{array}{c}103,0 \\
5\end{array}$ \\
\hline Mei & $\begin{array}{c}945600 \\
000\end{array}$ & 0.947 & $\begin{array}{c}69885 \\
7499\end{array}$ & 0.981 & 89,89 \\
\hline \multicolumn{7}{|c|}{} & & & $($ lanjut)
\end{tabular}


Tabel 11. Indeks Produktivitas Penggunaan Material (lanjutan)

\begin{tabular}{|c|c|c|c|c|c|}
\hline \multicolumn{6}{|c|}{ Tahun 2016-2017 } \\
\hline Bulan & $\begin{array}{c}\text { Kelu } \\
\text { aran } \\
\text { Materia } \\
\text { I (Rp) }\end{array}$ & $\begin{array}{l}\text { Ind } \\
\text { eks } \\
\text { Kelu } \\
\text { aran }\end{array}$ & $\begin{array}{l}\text { Masuk } \\
\text { an } \\
\text { Materi } \\
\text { al (Rp) }\end{array}$ & $\begin{array}{c}\text { Ind } \\
\text { eks } \\
\text { Masu } \\
\text { kan }\end{array}$ & $\begin{array}{c}\text { Ind } \\
\text { eks } \\
\text { Prod } \\
\text { uktivi } \\
\text { tas } \\
(\%)\end{array}$ \\
\hline Juni & $\begin{array}{c}888800 \\
000\end{array}$ & 0.890 & $\begin{array}{c}73078 \\
5000\end{array}$ & 0.990 & 79,89 \\
\hline Juli & $\begin{array}{c}936000 \\
000\end{array}$ & $\begin{array}{c}0.937 \\
5 \\
\end{array}$ & $\begin{array}{c}69176 \\
2501\end{array}$ & 0.793 & 94,36 \\
\hline $\begin{array}{c}\text { Agustu } \\
\mathrm{s}\end{array}$ & $\begin{array}{c}104640 \\
0000\end{array}$ & 1.033 & $\begin{array}{c}77335 \\
5001\end{array}$ & 0.985 & $\begin{array}{c}107,0 \\
8\end{array}$ \\
\hline $\begin{array}{l}\text { Septe } \\
\text { mber }\end{array}$ & $\begin{array}{c}110400 \\
0000\end{array}$ & 1.105 & $\begin{array}{c}81592 \\
5001\end{array}$ & 1.105 & $\begin{array}{c}100,0 \\
6\end{array}$ \\
\hline $\begin{array}{c}\text { Oktobe } \\
r\end{array}$ & $\begin{array}{c}960000 \\
000\end{array}$ & 0.961 & $\begin{array}{c}70950 \\
0001\end{array}$ & 1.019 & 98,13 \\
\hline $\begin{array}{c}\text { Novem } \\
\text { ber }\end{array}$ & $\begin{array}{c}113760 \\
0000\end{array}$ & 1.139 & $\begin{array}{c}82075 \\
7502\end{array}$ & 1.112 & $\begin{array}{c}102,5 \\
7\end{array}$ \\
\hline $\begin{array}{c}\text { Desem } \\
\text { ber }\end{array}$ & $\begin{array}{c}940800 \\
000\end{array}$ & 0.890 & $\begin{array}{c}69531 \\
0003\end{array}$ & 1.004 & 89,89 \\
\hline $\begin{array}{c}\text { Januar } \\
\mathrm{i}\end{array}$ & $\begin{array}{c}100800 \\
0000\end{array}$ & 0.961 & $\begin{array}{c}74497 \\
5004\end{array}$ & 1.009 & 95,24 \\
\hline$\underset{\text { ri }}{\text { Februa }}$ & $\begin{array}{c}108000 \\
0000\end{array}$ & 0.941 & $\begin{array}{c}79818 \\
7504\end{array}$ & 1.081 & 87,04 \\
\hline Maret & $\begin{array}{c}110400 \\
0000\end{array}$ & 1.105 & $\begin{array}{c}81592 \\
5004\end{array}$ & 1.105 & $\begin{array}{c}100,0 \\
5\end{array}$ \\
\hline April & $\begin{array}{c}113760 \\
0000\end{array}$ & 1.139 & $\begin{array}{c}84075 \\
7504\end{array}$ & 1.033 & 110,3 \\
\hline
\end{tabular}

\section{Produktivitas Tenaga Kerja}

IP Parsial $=($ AOMP $/$ AOBP $) /($ RIMP $/$ RIBP $) \times 100 \quad$ Pers. 7 $=(1017600000 / 998400000) /(155909999 /$ 155910000) x100 $=1.019 / 0,999 \times 100=102$

Perhitungan keseluruhan terdapat di Tabel 12

Tabel 12. Indeks Produktivitas Penggunaan Tenaga

\begin{tabular}{|c|c|c|c|c|c|}
\hline \multicolumn{1}{|c|}{ Kerja } & $\begin{array}{c}\text { Keluar } \\
\text { an } \\
\text { Tenag } \\
\text { a Kerja } \\
\text { (Rp) }\end{array}$ & $\begin{array}{c}\text { Ind } \\
\text { eks } \\
\text { Kelu } \\
\text { aran }\end{array}$ & $\begin{array}{c}\text { Masu } \\
\text { kan } \\
\text { Tenag } \\
\text { a } \\
\text { Kerja } \\
\text { (Rp) }\end{array}$ & $\begin{array}{c}\text { Ind } \\
\text { eks } \\
\text { Masu } \\
\text { kan }\end{array}$ & $\begin{array}{c}\text { Ind } \\
\text { eks } \\
\text { Produk } \\
\text { tivitas } \\
(\%)\end{array}$ \\
\hline $\begin{array}{c}\text { Janua } \\
\text { ri }\end{array}$ & $\begin{array}{c}998400 \\
000\end{array}$ & 1.000 & $\begin{array}{c}15591 \\
0000\end{array}$ & 1.000 & 100 \\
\hline $\begin{array}{c}\text { Febru } \\
\text { ari }\end{array}$ & $\begin{array}{c}101760 \\
0000\end{array}$ & 1.019 & $\begin{array}{c}15590 \\
9999\end{array}$ & 0.999 & 102 \\
\hline Maret & $\begin{array}{c}111360 \\
0000\end{array}$ & 1.117 & $\begin{array}{c}15591 \\
0000\end{array}$ & 0.999 & 111,81 \\
\hline April & $\begin{array}{c}103200 \\
0000\end{array}$ & 1.033 & $\begin{array}{c}15590 \\
9999\end{array}$ & 0.999 & 103,4 \\
\hline Mei & $\begin{array}{c}945600 \\
000\end{array}$ & 0.947 & $\begin{array}{c}15590 \\
9999\end{array}$ & 0,999 & 94,79 \\
\hline Juni & $\begin{array}{c}888800 \\
000\end{array}$ & 0.890 & $\begin{array}{c}15591 \\
0000\end{array}$ & 1.000 & 89 \\
\hline Juli & $\begin{array}{c}936000 \\
000\end{array}$ & 0.937 & $\begin{array}{c}15590 \\
9999\end{array}$ & 1.000 & 93,79 \\
\hline
\end{tabular}

Tabel 12. Indeks Produktivitas Penggunaan Tenaga Kerja (lanjutan)

\begin{tabular}{|c|c|c|c|c|c|}
\hline Bulan & $\begin{array}{c}\text { Keluar } \\
\text { an } \\
\text { Tenag } \\
\text { a Kerja } \\
\mathbf{( R p )}\end{array}$ & $\begin{array}{c}\text { Ind } \\
\text { eks } \\
\text { Kelu } \\
\text { aran }\end{array}$ & $\begin{array}{c}\text { Masu } \\
\text { kan } \\
\text { Tenag } \\
\mathbf{a} \\
\text { Kerja } \\
\mathbf{( R p )}\end{array}$ & $\begin{array}{c}\text { Ind } \\
\text { eks } \\
\text { Masu } \\
\text { kan }\end{array}$ & $\begin{array}{c}\text { Ind } \\
\text { eks } \\
\text { Produk } \\
\text { tivitas } \\
\mathbf{( \% )}\end{array}$ \\
\hline $\begin{array}{c}\text { Agust } \\
\text { us }\end{array}$ & $\begin{array}{c}104640 \\
0000\end{array}$ & 1.033 & $\begin{array}{c}15591 \\
0001\end{array}$ & 1.000 & 103,3 \\
\hline $\begin{array}{c}\text { Septe } \\
\text { mber }\end{array}$ & $\begin{array}{c}110400 \\
0000\end{array}$ & 1.105 & $\begin{array}{c}15591 \\
0001\end{array}$ & 1.000 & 110,5 \\
\hline $\begin{array}{c}\text { Oktob } \\
\text { er }\end{array}$ & $\begin{array}{c}960000 \\
000\end{array}$ & 0.961 & $\begin{array}{c}15591 \\
0001\end{array}$ & 1.000 & 96,1 \\
\hline $\begin{array}{c}\text { Nove } \\
\text { mber }\end{array}$ & $\begin{array}{c}113760 \\
0000\end{array}$ & 1.139 & $\begin{array}{c}15591 \\
0002\end{array}$ & 1.000 & 113,9 \\
\hline $\begin{array}{c}\text { Dese } \\
\text { mber }\end{array}$ & $\begin{array}{c}940800 \\
000\end{array}$ & 0.890 & $\begin{array}{c}15591 \\
0003\end{array}$ & 1.000 & 89 \\
\hline $\begin{array}{c}\text { Janua } \\
\text { ri }\end{array}$ & $\begin{array}{c}100800 \\
0000\end{array}$ & 0.961 & $\begin{array}{c}14685 \\
8004\end{array}$ & 0.941 & 102,12 \\
\hline $\begin{array}{c}\text { Febru } \\
\text { ari }\end{array}$ & $\begin{array}{c}108000 \\
0000\end{array}$ & 0.941 & $\begin{array}{c}14685 \\
8004\end{array}$ & 0.941 & 97,26 \\
\hline Maret & $\begin{array}{c}110400 \\
0000\end{array}$ & 1.105 & $\begin{array}{c}14685 \\
8004\end{array}$ & 0.941 & 87,22 \\
\hline $\begin{array}{c}113760 \\
0000\end{array}$ & 1.139 & $\begin{array}{c}14685 \\
8004\end{array}$ & 0.941 & 121,04 \\
\hline
\end{tabular}

\section{Produktivitas Energi}

IP Parsial

$=($ AOMP $/$ AOBP $) /($ RIMP $/$ RIBP $) \times 100$

Pers. 8

$=(1017600000 / 998400000) /(9.177 .999 /$

$$
6.100 .800) \times 100
$$

$=1.019 / 1.504 \times 100=67,75$

Tabel 13 menunjukan perhitungan keseluruhan

Tabel 13. Indeks Produktivitas Penggunaan Energi

\begin{tabular}{|c|c|c|c|c|c|}
\hline \multicolumn{6}{|c|}{ Tahun 2016-2017 } \\
\hline $\begin{array}{l}\text { Bul } \\
\text { an }\end{array}$ & $\begin{array}{c}\text { Keluara } \\
\text { n } \\
\text { Energi } \\
(\mathrm{Rp})\end{array}$ & $\begin{array}{l}\text { Ind } \\
\text { eks } \\
\text { Keluar } \\
\text { an }\end{array}$ & $\begin{array}{c}\text { Masuk } \\
\text { an } \\
\text { Energi } \\
(\mathrm{Rp})\end{array}$ & $\begin{array}{c}\text { Ind } \\
\text { eks } \\
\text { Masu } \\
\text { kan }\end{array}$ & $\begin{array}{c}\text { Ind } \\
\text { eks } \\
\text { Prod } \\
\text { uktiv } \\
\text { itas } \\
(\%)\end{array}$ \\
\hline $\begin{array}{l}\text { Jan } \\
\text { uari }\end{array}$ & $\begin{array}{c}998400 \\
000\end{array}$ & 1.000 & $\begin{array}{c}6.100 . \\
800\end{array}$ & 1.000 & 100 \\
\hline $\begin{array}{l}\text { Feb } \\
\text { ruari }\end{array}$ & $\begin{array}{c}101760 \\
0000\end{array}$ & 1.019 & $\begin{array}{c}9.177 . \\
999\end{array}$ & 1.504 & 67,75 \\
\hline $\begin{array}{c}\text { Mar } \\
\text { et }\end{array}$ & $\begin{array}{c}111360 \\
0000\end{array}$ & 1.117 & $\begin{array}{c}7.600 . \\
000\end{array}$ & 1.245 & 89,71 \\
\hline April & $\begin{array}{c}103200 \\
0000\end{array}$ & 1.033 & $\begin{array}{c}7.199 . \\
999\end{array}$ & 1.180 & 87,54 \\
\hline Mei & $\begin{array}{c}945600 \\
000\end{array}$ & 0.947 & $\begin{array}{c}9.699 . \\
999\end{array}$ & 1.590 & 59,56 \\
\hline Juni & $\begin{array}{c}888800 \\
000\end{array}$ & 0.890 & $\begin{array}{c}7.200 . \\
800\end{array}$ & 1.180 & 75,42 \\
\hline Juli & $\begin{array}{c}936000 \\
000\end{array}$ & 0.937 & $\begin{array}{c}5.250 . \\
901\end{array}$ & 0.860 & $\begin{array}{c}108,9 \\
5\end{array}$ \\
\hline $\begin{array}{l}\text { Agu } \\
\text { stus }\end{array}$ & $\begin{array}{c}104640 \\
0000\end{array}$ & 1.033 & $\begin{array}{c}8.000 \\
001\end{array}$ & 1.002 & 97,3 \\
\hline
\end{tabular}


Tabel 13. Indeks Produktivitas Penggunaan Energi (lanjutan)

\begin{tabular}{|c|c|c|c|c|c|}
\hline \multicolumn{6}{|c|}{ Tahun 2016-2017 } \\
\hline $\begin{array}{l}\text { Bul } \\
\text { an }\end{array}$ & $\begin{array}{c}\text { Keluara } \\
\text { n } \\
\text { Energi } \\
\text { (Rp) }\end{array}$ & $\begin{array}{l}\text { Ind } \\
\text { eks } \\
\text { Keluar } \\
\text { an }\end{array}$ & $\begin{array}{l}\text { Masuk } \\
\text { an } \\
\text { Energi } \\
\text { (Rp) }\end{array}$ & $\begin{array}{c}\text { Ind } \\
\text { eks } \\
\text { Masu } \\
\text { kan }\end{array}$ & $\begin{array}{c}\text { Ind } \\
\text { eks } \\
\text { Prod } \\
\text { uktiv } \\
\text { itas } \\
(\%)\end{array}$ \\
\hline $\begin{array}{l}\text { Sep } \\
\text { tem } \\
\text { ber }\end{array}$ & $\begin{array}{c}110400 \\
0000\end{array}$ & 1.105 & $\begin{array}{c}6.000 . \\
001\end{array}$ & 0.983 & $\begin{array}{c}112,4 \\
1\end{array}$ \\
\hline $\begin{array}{l}\text { Okt } \\
\text { ober }\end{array}$ & $\begin{array}{c}960000 \\
000\end{array}$ & 0.961 & $\begin{array}{c}7.624 . \\
301\end{array}$ & 1.088 & 91,91 \\
\hline $\begin{array}{l}\text { Nov } \\
\text { emb } \\
\text { er }\end{array}$ & $\begin{array}{c}113760 \\
0000\end{array}$ & 1.139 & $\begin{array}{c}5.800 \\
002\end{array}$ & 0.950 & $\begin{array}{c}119,8 \\
9\end{array}$ \\
\hline $\begin{array}{l}\text { Des } \\
\text { emb } \\
\text { er }\end{array}$ & $\begin{array}{c}940800 \\
000\end{array}$ & 0.9429 & $\begin{array}{c}7.400 . \\
893\end{array}$ & 1.213 & 77,65 \\
\hline $\begin{array}{l}\text { Jan } \\
\text { uari }\end{array}$ & $\begin{array}{c}100800 \\
0000\end{array}$ & 1.009 & $\begin{array}{c}7.300 . \\
804\end{array}$ & 1.196 & 84,36 \\
\hline $\begin{array}{l}\text { Feb } \\
\text { ruari }\end{array}$ & $\begin{array}{c}108000 \\
0000\end{array}$ & 1.081 & $\begin{array}{c}8.023 . \\
404\end{array}$ & 1.315 & 82,2 \\
\hline $\begin{array}{l}\text { Mar } \\
\text { et }\end{array}$ & $\begin{array}{c}110400 \\
0000\end{array}$ & 1.105 & $\begin{array}{c}8.500 . \\
004\end{array}$ & 1.393 & 79,32 \\
\hline April & $\begin{array}{c}113760 \\
0000\end{array}$ & 1.139 & $\begin{array}{c}9.700 \\
304\end{array}$ & 1.590 & 71,63 \\
\hline
\end{tabular}

\section{Produktivitas Maintenance}

IP Parsial

$=($ AOMP $/$ AOBP $) /($ RIMP $/$ RIBP $) \times 100$

Pers. 9

$=(1017600000 / 998400000) /(7124999 /$

$$
7443000) \times 100
$$

$=1.019 / 0,967 \times 100=107,47$

Tabel 14 menunjukkan perhitungan keseluruhan

Tabel 14. Indeks Produktivitas Penggunaan Maintenance

\begin{tabular}{|c|c|c|c|c|c|}
\hline \multicolumn{7}{|c|}{ Tahun 2016-2017 } \\
\hline $\begin{array}{c}\text { Bula } \\
\text { n }\end{array}$ & $\begin{array}{c}\text { Keluar } \\
\text { an } \\
\text { Maint } \\
\text { enanc } \\
\text { e (Rp) }\end{array}$ & $\begin{array}{c}\text { Ind } \\
\text { eks } \\
\text { Kelu } \\
\text { aran }\end{array}$ & $\begin{array}{c}\text { Masu } \\
\text { kan } \\
\text { Maint } \\
\text { enanc } \\
\text { e (Rp) }\end{array}$ & $\begin{array}{c}\text { Ind } \\
\text { eks } \\
\text { Masu } \\
\text { kan }\end{array}$ & $\begin{array}{c}\text { Indek } \\
\text { s } \\
\text { Produ } \\
\text { ktivita } \\
\text { s (\%) }\end{array}$ \\
\hline $\begin{array}{c}\text { Janu } \\
\text { ari }\end{array}$ & $\begin{array}{c}99840 \\
0000\end{array}$ & 1.000 & $\begin{array}{c}74430 \\
00\end{array}$ & 1.000 & 100 \\
\hline $\begin{array}{c}\text { Febr } \\
\text { uari }\end{array}$ & $\begin{array}{c}10176 \\
00000\end{array}$ & 1.019 & $\begin{array}{c}71249 \\
99\end{array}$ & 0.957 & 106,47 \\
\hline Maret & $\begin{array}{c}11136 \\
00000\end{array}$ & 1.117 & $\begin{array}{c}88480 \\
00\end{array}$ & 1.188 & 99,91 \\
\hline April & $\begin{array}{c}10320 \\
00000\end{array}$ & 1.033 & $\begin{array}{c}77679 \\
99\end{array}$ & 1.043 & 99,04 \\
\hline Mei & $\begin{array}{c}94560 \\
0000\end{array}$ & 0.947 & $\begin{array}{c}96979 \\
99\end{array}$ & 1.302 & 72,73 \\
\hline Juni & $\begin{array}{c}88880 \\
0000\end{array}$ & 0.890 & $\begin{array}{c}42680 \\
00\end{array}$ & 0.573 & 155,32 \\
\hline Juli & $\begin{array}{c}93600 \\
0000\end{array}$ & 0.937 & $\begin{array}{c}96600 \\
01\end{array}$ & 0.583 & 171,52 \\
\hline
\end{tabular}

Tabel 14. Indeks Produktivitas Penggunaan Maintenance (lanjutan)

\begin{tabular}{|c|c|c|c|c|c|}
\hline \multicolumn{6}{|c|}{ Tahun 2016-2017 } \\
\hline$\underset{n}{\text { Bula }}$ & $\begin{array}{c}\text { Keluar } \\
\text { an } \\
\text { Maint } \\
\text { enanc } \\
\text { e (Rp) }\end{array}$ & $\begin{array}{l}\text { Ind } \\
\text { eks } \\
\text { Kelu } \\
\text { aran }\end{array}$ & $\begin{array}{c}\text { Masu } \\
\text { kan } \\
\text { Maint } \\
\text { enanc } \\
\text { e (Rp) }\end{array}$ & $\begin{array}{c}\text { Ind } \\
\text { eks } \\
\text { Masu } \\
\text { kan }\end{array}$ & $\begin{array}{c}\text { Indek } \\
\text { s } \\
\text { Produ } \\
\text { ktivita } \\
\text { s (\%) }\end{array}$ \\
\hline $\begin{array}{l}\text { Agust } \\
\text { us }\end{array}$ & $\begin{array}{l}10464 \\
00000\end{array}$ & 1.033 & $\begin{array}{c}44500 \\
01\end{array}$ & 0.527 & 185 \\
\hline $\begin{array}{c}\text { Sept } \\
\text { embe } \\
r\end{array}$ & $\begin{array}{l}11040 \\
00000\end{array}$ & 1.105 & $\begin{array}{c}53500 \\
01\end{array}$ & 0.752 & 124,17 \\
\hline $\begin{array}{c}\text { Okto } \\
\text { ber }\end{array}$ & $\begin{array}{c}96000 \\
0000\end{array}$ & 0.961 & $\begin{array}{c}78500 \\
01\end{array}$ & 0.929 & 107,64 \\
\hline $\begin{array}{l}\text { Nove } \\
\text { mber }\end{array}$ & $\begin{array}{l}11376 \\
00000\end{array}$ & 1.139 & $\begin{array}{c}54800 \\
02\end{array}$ & 0,649 & 140,01 \\
\hline $\begin{array}{l}\text { Dese } \\
\text { mber }\end{array}$ & $\begin{array}{c}94080 \\
0000\end{array}$ & 0.941 & $\begin{array}{c}85000 \\
03\end{array}$ & 1.142 & 89,24 \\
\hline $\begin{array}{c}\text { Janu } \\
\text { ari }\end{array}$ & $\begin{array}{l}10080 \\
00000\end{array}$ & 1.009 & $\begin{array}{c}62500 \\
04\end{array}$ & 0.858 & 112 \\
\hline $\begin{array}{l}\text { Febr } \\
\text { uari }\end{array}$ & $\begin{array}{l}10800 \\
00000\end{array}$ & 1.081 & $\begin{array}{c}75000 \\
04\end{array}$ & 1.007 & 107,34 \\
\hline Maret & $\begin{array}{l}11040 \\
00000\end{array}$ & 1.105 & $\begin{array}{c}58000 \\
04\end{array}$ & 0.779 & 128,2 \\
\hline April & $\begin{array}{l}11376 \\
00000\end{array}$ & 1.139 & $\begin{array}{c}80000 \\
04\end{array}$ & 1.074 & 106,05 \\
\hline
\end{tabular}

\section{Perhitungan Indeks produktivitas Total}

IP Total
$=(1017600000 / 998400000) /(932531795 /$ $915926300) \times 100$
Pers. 10

$=1.019 / 1.018 \times 100=98,33$

Tabel 15 menunjukkan perhitungan keseluruhan.

Tabel 15. Indeks Produktivitas Total

\begin{tabular}{|c|c|c|c|}
\hline \multicolumn{4}{|c}{ Tahun 2016-2017 } \\
\hline Bulan & $\begin{array}{c}\text { AOP } \\
\text { Total }\end{array}$ & RIP Total & $\begin{array}{c}\text { Indeks } \\
\text { Produktivitas } \\
\text { (\%) }\end{array}$ \\
\hline Januari & $\begin{array}{c}99840 \\
0000\end{array}$ & 915.926 .300 & 100,38 \\
\hline Februari & $\begin{array}{c}10176 \\
00000\end{array}$ & 932.531 .795 & 98,33 \\
\hline Maret & $\begin{array}{c}11136 \\
00000\end{array}$ & $\begin{array}{c}1.004 .314 .20 \\
0\end{array}$ & 90,08 \\
\hline April & $\begin{array}{c}10320 \\
00000\end{array}$ & 942.526 .695 & 111,282 \\
\hline Mei & $\begin{array}{c}94560 \\
0000\end{array}$ & 882.757 .995 & 99,61 \\
\hline Juni & $\begin{array}{c}88880 \\
0000\end{array}$ & 905.756 .300 & 102,03 \\
\hline Juli & $\begin{array}{c}93600 \\
0000\end{array}$ & 771.519 .605 & 111,61 \\
\hline Agustus & $\begin{array}{c}10464 \\
00000\end{array}$ & 950.307 .505 & 113,78 \\
\hline Septembe & $\begin{array}{c}11040 \\
00000\end{array}$ & 992.121 .205 & 98,74 \\
\hline Oktober & $\begin{array}{c}96000 \\
0000\end{array}$ & 789.476 .805 & 108,72 \\
\hline November & $\begin{array}{c}11376 \\
00000\end{array}$ & 916.883 .710 & 102,27 \\
\hline
\end{tabular}


Tabel 15 Indeks Produktivitas Total (lanjutan)

\begin{tabular}{|c|c|c|c|}
\hline \multicolumn{4}{|c|}{ Tahun 2016-2017 } \\
\hline Bulan & $\begin{array}{c}\text { AOP } \\
\text { Total }\end{array}$ & RIP Total & $\begin{array}{c}\text { Indeks } \\
\text { Produktivitas } \\
(\%)\end{array}$ \\
\hline Desember & $\begin{array}{c}94080 \\
0000\end{array}$ & 874.613 .405 & 102,69 \\
\hline Januari & $\begin{array}{c}10080 \\
00000\end{array}$ & 914.320 .020 & 102,89 \\
\hline Februari & $\begin{array}{c}10800 \\
00000\end{array}$ & 968.817 .720 & 82,75 \\
\hline Maret & $\begin{array}{c}11040 \\
00000\end{array}$ & 985.675 .520 & 102,69 \\
\hline April & $\begin{array}{c}11376 \\
00000\end{array}$ & $\begin{array}{c}1.014 .252 .17 \\
0\end{array}$ & 102,89 \\
\hline
\end{tabular}

\section{Analisa Hasil Pengukuran Produktivitas}

Berikut ini akan diuraikan hubungan antara faktor-faktor input dengan hasil pengukuran produktivitas untuk memudahkan dalam pengendalian produktivitas yang bertujuan untuk meningkatkan produktivitas pada periode selanjutnya. Setiap fluktuasi produktivitas dapat dilihat pada Gambar 2, 3, 4, 5, dan 6 .

\section{a. Analisa Indeks Produktivitas Parsial}

1) Produktivitas Depresiasi

Periode pengukuran indeks produktivitas depresiasi cenderung fluktuatif. Indeks Produktivitas Tertinggi dicapai pada bulan April 2017 sebesar 109,51\%. Dan indeks terendah terjadi pada bulan Juni 2016 sebesar $79 \%$.

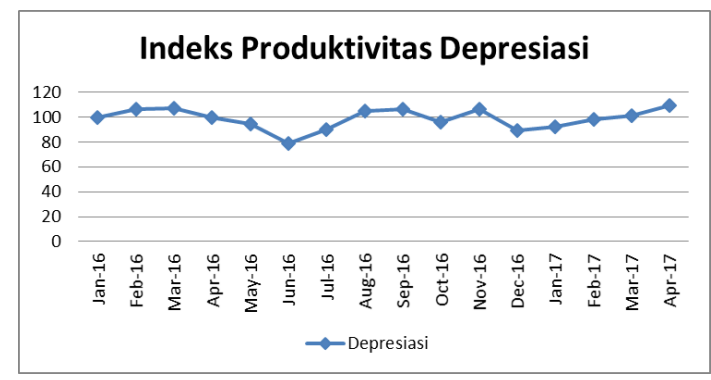

Gambar 2. Fluktuasi Produkvitas Depresiasi

2) Produktivitas Material

Periode pengukuran indeks produktivitas material cenderung berfluktuasi. Indeks Produktivitas tertinggi dicapai pada bulan April 2017 sebesar 110,3\% dan indeks terendah terjadi pada bulan Juni 2016 sebesar $79 \%$.

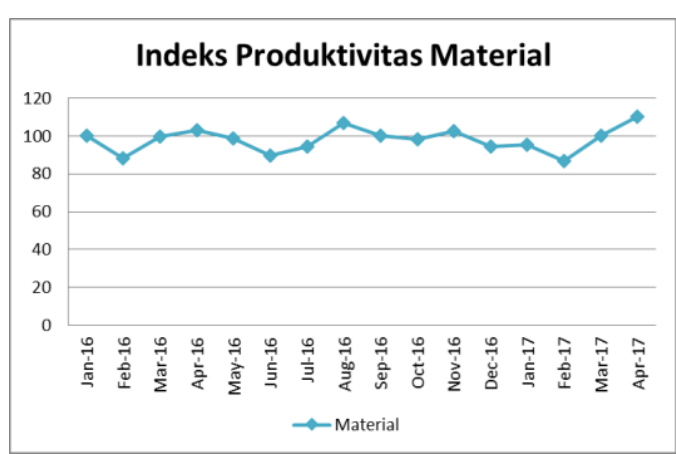

Gambar 3. Fluktuasi Produkvitas Material

3) Produktivitas Tenaga Kerja

Indeks Produktivitas tertinggi dicapai pada bulan April 2017 sebesar 121,04 \%. Dan indeks terendah terjadi pada bulan Juni 2016 sebesar $89 \%$.

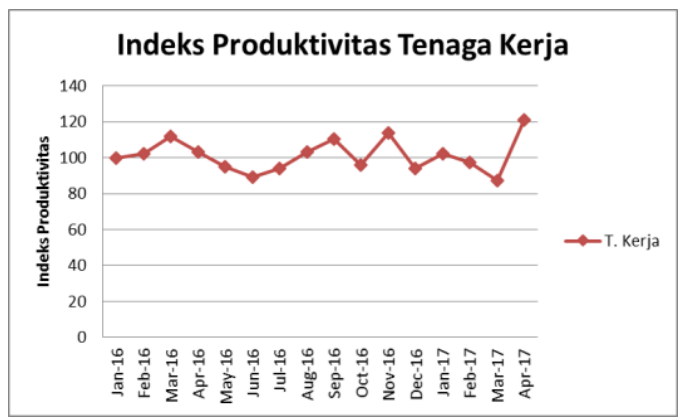

Gambar 4. Fluktuasi Produkvitas T. Kerja

4) Produktivitas Energi

Indeks Produktivitas Tertinggi dicapai pada bulan November 2016 sebesar 119,89\%. Dan indeks terendah terjadi pada bulan April 2016 sebesar 59,56 \%.

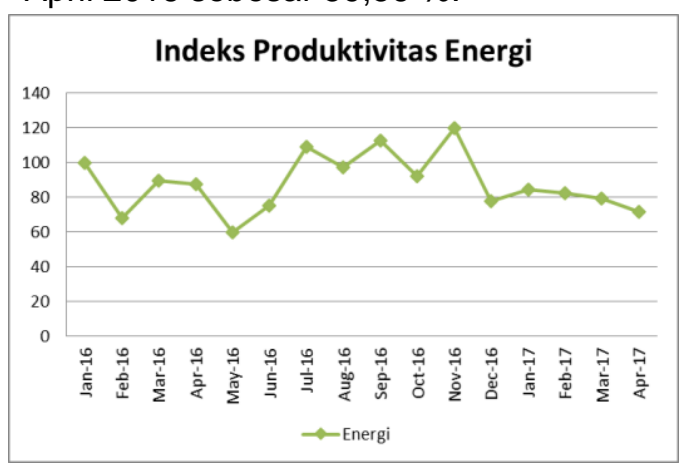

Gambar 5. Fluktuasi Produkvitas Energi

5) Indeks Produktivitas Maintenance Indeks Produktivitas Tertinggi dicapai pada bulan Agustus 2016 sebesar $185 \%$. Dan indeks terendah terjadi pada bulan Mei 2016 sebesar $72,73 \%$. 


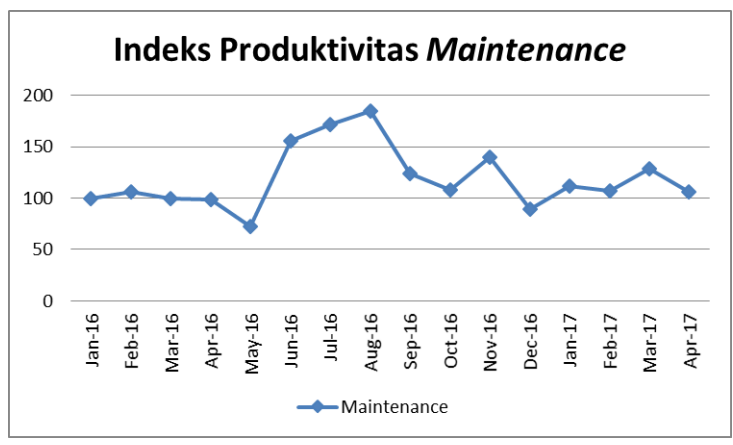

Gambar 6. Fluktuasi Produkvitas Maintenance

\section{b. Analisa Indeks Produktivitas Total}

Indeks produktivitas total diperoleh dari perbandingan antara seluruh keluaran yaitu produk dengan masukan yaitu material, energi, depresiasi, tenaga kerja dam maintenancei yang dapat dilihat pada Gambar 7.

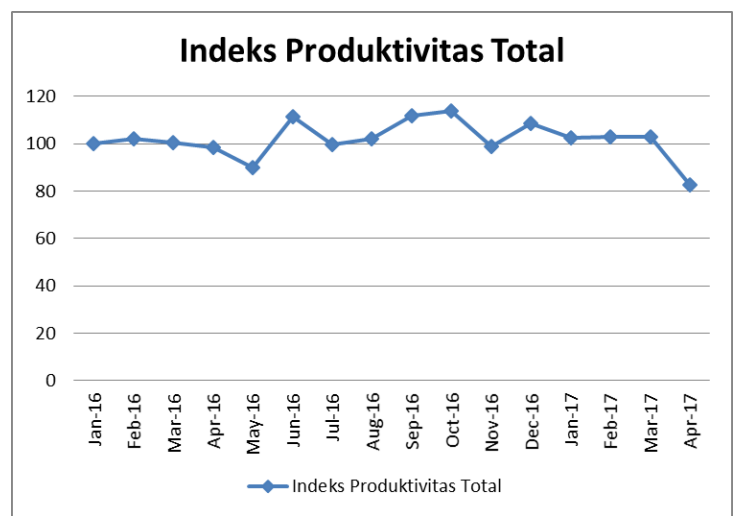

Gambar 7. Fluktuasi Produkvitas Total

Dari Gambar 7 menunjukkan indeks produktivitas total cenderung berfluktuasi naik dan turun hal ini perlu diperhatikan oleh perusahaan agar produktivitas mengalami peningkatan setiap bulannya.

\section{Kesimpulan dan Saran}

Dengan menggunakana pengukuran produktivitas metode Marvin E. Mundel dan menetapkan bulan januari tahun 2016 sebagai periode dasar maka dapat dilihat indeks produktivitas energi, maintenance, depresiasi, tenaga kerja dan material perusahaan. Implikasi dari penelitian ini adalah perbaikan dan peningkatan produktifitas di CV. Gavra Perkasa untuk periode yang akan datang dapat dilakukan dengan alat bantu diagram sebab akibat. Dari diagram sebab akibat ini diharapkan dapat memberikan analisis yang tepat dalam mengidentifikasikan penyebabpenyebab masalah produktifitas perusahaan sehingga untuk selanjutnya untuk selanjutnya dapat diberikan pemecahan atas maslah yang terjadi dan dapat meningkatkan produktivitas dari segi kualitasnya.

\section{Daftar Pustaka}

Bakar, A., Suprianto, O., \& Yuniati, Y. (2017). Usulan Peningkatan Produktivitas Berdasarkan Metode Mundel dan Apc di PT. Raffsya Media. Journal of Industrial Engineering Management, 2(2), 1-13.

Kurniawan, C., Tjahyono, R., \& Izzhati, D. N. (2017). Pemodelan dan Analisa Produktivitas Proses Pembekuan Produk Fillet Ikan Menggunakan Objective Matrix (OMAX)(Studi Kasus PT. Mandala Mulya Sakti Surabaya). Applied Industrial Engineering Journal, 1(2), 53-64.

Kusumanto, I. (2016). Analisis Produktivitas PT. Perkebunan Nusantara V (PKS) Sei Galuh Dengan Menggunakan Metode American Productivity Center (APC). JTI: Jurnal Teknik Industri, 2(2), 129-139.

Mahaputra, M. S. (2018). Pengukuran Kinerja Perusahaan Produktivitas Menggunakan Marvin E. Metode Mundel Dan Analisa Swot Pada Pt Pt. Esbe Gas Putra Bandung. NUSTRIAL, 1(1).

Mubin, A., \& Zainuri, S. (2012). Peningkatan Produktivitas Dan Kinerja Lingkungan Dengan Metode Green Productivity di PT. XYZ. Jurnal Teknik Industri, 13(2), 126-132.

Rejeki, K. S., Sinulingga, S., \& Tarigan, U. (2013). Evaluasi dan analisis produktivitas dengan menggunakan metode Marvin E. Mundel di PT. XYZ. Jurnal Teknik Industri USU, 2(1).

Ristanti, D. M. R., \& Prabowo, R. (2018, October). Analisis produktivitas dengan pendekatan metode apc di perusahaan jasa uji tak merusak/ndt. In Conference on Innovation and Application of Science and Technology (CIASTECH) (Vol. 1, No. 1, pp. 469-477).

Sarjono, H. (2001). Metode Perhitungan Angka Indeks Produktivitas Menggunakan Model Marvin E Mundel. The Winners, 2(1), 18-24.

Siahaya, S. L. (2017). Pengukuran Produktivitas Kinerja Usaha Mikro Gula Merah Saparua. Jurnal Maneksi, 6(2), 7-11.

Singgih, M. L. (2008). Pengukuran Produktivitas Personel dalam Penentuan Pemberian Insentif Karyawan di Perusahaan Pembangkit Listrik. Jurnal Teknik Industri, 8(1), 60-66. 